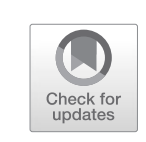

\title{
Domestic Violence: The Qur'an Does Not Instruct Husbands to Hit Their Wives for "Disobedience" or Anything Else
}

\section{Qur'anic Verses That Prove That Wife-Hitting Is NOT PRESCRIBED}

Arguably the most contentious verse in the Qur'an relating to women is verse $4: 34$, which some incorrectly claim instructed husbands to hit their wives if they disobey them. Before delving into this one, let us ask ourselves one question: Does this make sense in light of all the verses we have looked at so far that relate to women? Does it make sense that God would sabotage His own efforts at establishing equal social dignity and responsibility for women and men alike by suddenly telling husbands they can hit their wives?

Throughout this book, I have tried to emphasise how important it is to not single out a verse in isolation, to not look at a single tree, lest the message or forest as a whole be missed. At the risk of repeating myself, this means two things:

- A verse must be considered not just in its entirety but alongside the verses preceding and following it before we decide what it means, otherwise we might inadvertently go down the wrong track or simply miss the point. Certainly, some verses and phrases are standalones, but many are not.

- A verse on a specific topic must also be considered alongside all other verses in the Qur'an that deal with that same topic. 
Verse 4:34 might be a familiar verse number to the reader by now because we have actually discussed it already, in Part III under Chap. 11 's sections "Guardianship" and "Participation", and in Chap. 12, entitled Inheritance and Chap. 15, entitled Divorce. This is because it is a relatively long verse that touches on several topics all at once, both directly and indirectly.

Let us now look at 4:34 alongside its neighbouring as well as other verses in the Qur'an that deal with one particular topic that it also addresses: nushooz.

\section{Women, 4:34-35}

Men are upholders/maintainers (qawwamūn) of women with whatever God has favoured some [men] with over others [other men], and with whatever they spend of their wealth [on the women]. Therefore righteous women are devoutly pious (qanitāt), keeping private what God has ordained be so-kept. As for those (women) whom you fear (have committed) a promiscuous act (nushooz), admonish (pl.) them, abstain from them in bed, strike them. But if they heed you (pl.) [i.e. your admonishment], then do not (pl.) look for a way against them. For God is Exalted, Great.

And if you fear a breach may occur between the two of them [i.e. the husband and wife in question], then send an arbiter from his family and an arbiter from her family. If the two of them wish to fix things, God will bring about agreement between them. For God is all-Knowing, all-Aware.

When 4:34 is read all the way to the end and the ensuing verse 4:35 which continues the narrative is read together with it, the effective phrase "strike them but not if they heed your counsel" is obviously revisiting the question of adultery discussed in the previous chapter, where a repentant unfaithful wife (or husband) is to be forgiven by society $(25: 68-71)$ and not flogged/struck to cause shame even if there are witnesses to the fact. In other words, the whole of verse $4: 34$ is addressing society as a whole, the last part dealing specifically with adultery ${ }^{1}$ and not just any husband-wife situation, while verse 4:35 goes on to deliver on God's

\footnotetext{
${ }^{1}$ See Abou El Fadl, Khaled M. 2006. The Search for Beauty in Islam: A Conference of the Books. Maryland: Rowman \& Littlefield Publishers, Inc., 109-112. Also see Brown, Jonathan. 2015. Misquoting Muhammad: The Challenge and Choices of Interpreting the Prophet's Legacy. London: Oneworld Publications, 280 regarding Ibn 'Ashur on how a legal approach to "strike them" in 4:34 necessarily requires that a person involved in a case not also be its judge and enforcer.
} 
promise to forgive an adulteress (or adulterer) by intervening Himself to reconcile the couple in question-a divine act of compassion towards us reminiscent of that of a loving and concerned grandparent.

So verses 4:34-35 are in fact a case study offered by the Qur'an on how to implement the penalty for adultery thoughtfully. That the subject of these verses, nushooz, refers to "a promiscuous act" (for lack of a better expression) is confirmed in two ways:

- Within verse 4:34 itself, by the instruction to men/husbands to "abstain from them (women) in bed"; and

- By another verse later in the same chapter where the word nushooz appears again, this time in relation to men. As we have seen throughout this book, the Qur'an does not let a single opportunity go by without establishing moval symmetry in God's approach to women and men. The verse where nushooz is applied to men is $4: 128$ and its neighbouring verses (which reinforce the meaning of 4:34 as maintained above) will be familiar as we visited them also in Part III where we discussed how monogamy is the norm in the Qur'an and how polygyny was related to "orphaned", i.e. widowed or bereaved women:

\section{Women, 4:127-130}

They consult you about women. Say: God instructs you about them, and what is recited to you in the Book regarding the orphaned women-whom you do not give what has been decreed as their rightful due yet whom you desire to marry-and the helpless among the children: that you should uphold justice for the orphans...

And if a woman fears that her husband (has committed) a promiscuous act (nushooz) or neglected her, there is no blame on either of them if they fix things in reconciliation, for reconciliation is best. Souls are prone to greed, but if you (pl.) do good and are reverent, God is surely aware of all you do. $(4: 128)$

You (pl.) will not be able to deal justly between women, however much you wish to. But do not turn away from one altogether so as to leave her suspended [i.e. in limbo, neither happily married nor free to move on]; and if you come to an agreement and are reverent, God is Forgiving, Merciful.

But if the two separate, God will compensate each of them from His abundance. For God is all-Embracing, Wise. 
In other words, verses 4:127-130 above tell us that people are greedy by nature and so men are likely to take more than one wife, which the Qur'an was allowing only in the case of widowed or bereaved women left without support (discussed at length in Part III under Marriage/monogamy). At the same time, God makes clear His lack of enthusiasm for men taking another wife by literally calling it an act of greed, and goes so far as to state unequivocally that $\mathrm{He}$ does not think men can ever be fair that way. But if the first wife and the husband can still make their relationship work, God will understand and if they cannot and decide to separate, God promises to also understand and, moreover, compensate both: the initial wife for ending up divorced for not wanting to share her husband, and the husband for agreeing to separate rather than be de facto unfair to his wife.

This is how the "strike them" part of verse 4:34 should be looked at, namely in its own context as well as together with other verses dealing with the same act, namely nushooz or promiscuous act. The two nushooz verses 4:34 and 4:128 apply to women and men, respectively and are two sides of the same coin: the Qur'an could have referred to the illicit sexual act by a married woman in $4: 34$ as zina (adultery), but it does not do so precisely to establish symmetry in its approach to men and women, as it could not logically have also called a man taking a second wife zina (adultery) since the Qur'an itself was allowing polygyny under certain conditions.

In fact if we line up the verses mentioning nushooz next to one another, their symmetry not just in content but also in language is striking and again reinforces the meaning above, namely that "strike them" refers to the societal penalty of "flogging" to shame in cases of witnessed and unrepentant adultery, and is not authorisation of domestic violence by a husband against his wife. Here they are in slightly shortened form to drive the point home:

...As for those (women) whom you fear (have committed) a promiscuous act (nushooz), admonish (pl.) them, abstain from them in bed, strike them. But if they heed you (pl.) [i.e. your admonishment], then do not (pl.) look for a way against them. For God is Exalted, Great. (4:34)

And if you fear a breach may occur between the two of them [i.e. the husband and wife], then send an arbiter from his family and an arbiter from her family. If the two of them wish to reconcile, God will bring about agreement between them. For God is all-Knowing, all-Aware. (4:35) 
and

And if a woman fears that her husband (has committed) a promiscuous act (nushooz) or neglected her, there is no blame on either of them if they reconcile, for reconciliation is best. Souls are prone to greed, but if you (pl.) do good and are reverent, God is surely aware of all you do. (4:128)

You (pl.) will not be able to deal justly between women, however much you wish to. But do not turn away from one altogether so as to leave her suspended... (4:129)

But if the two separate, God will compensate each of them from His abundance...(4:130)

Notice how in 4:35, God explicitly supports reconciliation between the couple if they so wish despite the wife's infidelity-precisely what the Prophet is reported to have done in the hadith quoted at the end of the previous chapter when the wronged husband declares that he still loves his unfaithful and promiscuous wife regardless.

So why has "strike them" in verse 4:34 not been interpreted or explained to us this way? Even past ${ }^{2}$ and present religious authorities, who thankfully roundly reject the idea that husbands are allowed to hit their wives, mostly argue their case indirectly:

- By pointing to the Prophet as an emancipating, kind and respectful husband who moreover instructed his followers to not hit women and to always treat them with respect.

- And/or pointing to the "gradual" instructions of the verse where the striking only takes effect if counsel is not heeded and marital abstention ("abstain from them in bed") does not do the trick.

- And/or, especially in contemporary scholarship, by arguing that the word "strike" is used in different ways in the Qur'an and may in this instance mean "strike or turn away" or "withdraw completely".

But the direct answer lies in the fact that jurists and commentators have not usually interpreted nushooz to refer to anything sexual, opting for far broader concepts:

\footnotetext{
${ }^{2}$ Pre-modern jurists were in fact surprisingly unanimous in rejecting the chauvinist interpretation of "strike them" in verse 4:34, while the majority of pre-modern courts also "were surprisingly receptive to women seeking redress or protection from spousal abuse." See Brown, Jonathan. Ibid., 274-287.
} 
- When nushooz is applied to women (4:34), it has mostly been translated as rebelliousness or arrogance, but also more mildly as ill conduct, discord, or animosity, all of which take the "strike them" out of the societal realm and into the private domain of the husband vis-à-vis his wife, hence the problem.

(When nushooz is applied to men (4:128), it has usually been translated as ill treatment, cruelty or animosity.)

But the subject in both 4:34 and 4:128 is in fact one and the same: a second partner in addition to the current spouse. As already mentioned, the promiscuous act of a married woman would constitute an unmarried and therefore illicit act from the Qur'anic point of view, hence the mention of a penalty in the case of the woman in $4: 34$. But the promiscuous act of a married man is not necessarily an unmarried/illicit act and in 4:128 it in fact refers to the specific case where men were permitted, though discouraged, by the Qur'an to take another wife.

It is this resistance to interpreting and translating nushooz as a promiscuous or extra-spousal act in both the case of men and women that has led us down this path where some think that domestic violence is approved by the Qur'an. In my view, much of this resistance is likely due, once again, to the inertia created by the repetition of the same thing over and over again down the generations.

\section{The Pushback of Myth on the Qur'an Itself: But God Told Job to Hit His Wife-It Says So IN THE QUR'An!}

During a workshop I was running overseas a few years ago on human rights and the Qur'an, I had been speaking about verse 4:34 partly along the lines detailed above when a woman participant raised her hand and said: But God told the prophet Job in the Qur'an to hit his wife!

I am not often left speechless, but I recall being so taken aback that I hesitated for a few seconds before saying anything. Then I asked: In the Qur'an? Yes, she said emphatically, and suddenly I became aware of many participants in the room gently shaking their heads in agreement. I looked around at the room full of women and I will never forget the big, concerned eyes and gravity of expression everyone seemed to have. None of the participants spoke or read Arabic or English and in fact I was holding 
the workshop through a translator, so I understood that whatever Qur'an they had read must have been in their own language. But I did not want to jump to conclusions, so I told the group that I had read the Qur'an dozens of times during the course of my life and that I could assure them that nowhere in it does God tell Job to hit his wife, that I did not recall Job's wife ever being mentioned even, but that I would look into it and get back to them after I returned home and had had a chance to investigate.

And indeed, while Job is mentioned four times ${ }^{3}$ in the Qur'an as one of God's prophets, I could not find a mention of his wife. One of these mentions is this sequence:

Sãd (unknown meaning but aka David), 38:41-44

And remember our servant Job, when he called out to his Lord: Satan has afflicted me with weariness and suffering!

Stamp your foot [came the reply]: Here is cool water to wash with and to drink.

And We bestowed upon him his family, and with them others like them, as a mercy from Us and as a reminder for those of understanding.

And take a bunch of grass in your hand and strike with it, and do not break your oath. Truly We found him steadfast—an excellent servant, ever turning (to God).

The verses above clearly speak of the long-suffering Job's resilient faith and steadfastness in the face of relentless onslaught by Satan. Mention of Job's family is made and it is highly positive, with no mention of his wife or any other woman or individual for that matter.

But to my dismay, as I looked up more and more English translations, I found that some of them had inserted either the words "your wife", (your wife), or (her) into verse 38:44 after the word "strike", to the following effect:

$\times$ And take a bunch of grass in your hand and strike your wife/(your wife) $/$ (her) with it, and do not break your oath. Truly We found him steadfast—an excellent servant, ever turning (to God).

${ }^{3} \mathrm{Job}$ is mentioned in the Qur'an as one of God's prophets in verses 4:163, 6:84, 21:83-84 and $38: 41-44$. 
which is in stark contrast to the original, which thankfully many popular translations did effectively maintain as:

$\checkmark$ And take a bunch of grass in your hand and strike with it, and do not break your oath. Truly We found him steadfast-an excellent servant, ever turning (to God). (38:44)

Why would anyone do this, and how can such audacious tampering ever be justified?

Apparently several classical commentators, mostly from the twelfth to the fourteenth centuries, ${ }^{4}$ had argued that Job's wife at one point got fed up with all the trials her husband was going through and reproached him for continuing to believe in God, an account they had most probably encountered in the Bible, in Job 2:9. ${ }^{5}$ But these commentators then added their own imaginings to the biblical account: that Job had replied in anger that if he ever got his health back he would strike her a hundred times for such blasphemy, but that when he did get better he regretted this "oath", and that God had therefore instructed him to take a handful of grass and hit his wife with it instead, so that he would neither be "breaking his oath" nor really harming her at the same time. ${ }^{6}$

At worst, I suppose we should be pleased that even this interpretation shows God trying to protect the wife!

But the truth of the matter is, besides the fact that there can never be any justification for importing foreign words into a Qur'anic verse, this bizarre interpretation is utterly unconvincing:

- These commentators or "interpreters" did not substantiate their expanded understanding of this verse in any way.

- The verses before 38:44 which speak of Job do not refer to his wifethe only other reference is to Satan. And Job's wife is not mentioned at all anywhere in the Qur'an.

\footnotetext{
${ }^{4}$ Nasr, Seyyed Hossein (editor-in-chief) et al. 2015. The Study Quran: A New Translation and Commentary. New York: HarperCollins Publishers, 1111 and lvii-lix.

${ }^{5}$ Asad, Muhammad. 2003. The Message of the Qur'an. Bristol, England: The Book Foundation, 789.

${ }^{6}$ Nasr et al. Op. Cit., 1111.

${ }^{7}$ See Nasr et al. Op. Cit., 1111 and Asad, Muhammad. Op. Cit., 789.
} 
- In fact, there is no mention of Job's wife anywhere in hadith either, ${ }^{8}$ so this interpretation cannot even be blamed on inauthentic hadith, the usual cause behind women-unfriendly interpretations.

- And lastly, not keeping an oath is not always condemned in the Qur'an so this argument rings hollow: for example, "God will not take you to task for the frivolous in your oaths..." (5:89), and "Do not make God an obstacle, through your oaths, to doing good and being reverent and reconciling between people... God will not take you to task for the frivolous in your oaths..." (2:224-225)

There can be no doubt, therefore, that $38: 44$ simply means what one initially understands it to mean: that God is telling Job to take a handful of grass and strike with it symbolically at Satan to brush away his tormentor and not lose faith. ${ }^{9}$ In fact the Arabic words used (la tabhnuth) mean both "do not break your oath" and "do not lean towards the wrong", which is what giving in to Satan's whisperings would constitute.

This incident with Job is reminiscent of another involving Abraham, who threw pebbles at Satan when the latter tried to tempt him into disobeying God's command to sacrifice his son, a symbolic act re-enacted by millions annually as one of the rites at the annual pilgrimage (hajj) in Mecca.

${ }^{8}$ Nasr et al. Op. Cit., 1111.

${ }^{9}$ An alternative interpretation of verse $38: 44$ is that "take a bunch of grass" relates to some herbal cure being recommended to the ailing Job. See Nasr et al. Op. Cit., 1111. 
Open Access This chapter is licensed under the terms of the Creative Commons Attribution 4.0 International License (http://creativecommons.org/licenses/ by $/ 4.0 /$ ), which permits use, sharing, adaptation, distribution and reproduction in any medium or format, as long as you give appropriate credit to the original author(s) and the source, provide a link to the Creative Commons licence and indicate if changes were made.

The images or other third party material in this chapter are included in the chapter's Creative Commons licence, unless indicated otherwise in a credit line to the material. If material is not included in the chapter's Creative Commons licence and your intended use is not permitted by statutory regulation or exceeds the permitted use, you will need to obtain permission directly from the copyright holder.

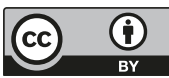

